\title{
Boiardo and Ariosto in Contemporary Sicilian Puppet Theater and the Tuscan-Emilian Epic Maggio
}

\author{
๘ \\ Jo Ann Cavallo
}

Characters from medieval and Renaissance chivalric texts have been given tangible form through the centuries not only in operatic, melodramatic, theatrical and, more recently, cinematic adaptations, but also in popular performance traditions such as Sicilian puppet theater (opera dei pupi) and the folk operas (maggi epici) of the Tuscan-Emilian Apennines. This essay traces the reimagining of a sampling of nonChristian characters and non-European places from Matteo Maria Boiardo's Orlando Innamorato and Ludovico Ariosto's Orlando Furioso by a number of contemporary puppet theater and maggio companies. My contention is that an examination of select scenes available online, in conjunction with a close reading of the original episodes, may help students think more deeply about perennial issues addressed in the two poems-related to gender roles, the foreign and religious Other, violence, and political power-that continue to be relevant today. ${ }^{1}$

\footnotetext{
${ }^{1}$ The links for the videos discussed in the essay will be provided in the following endnotes. There is additional material from both traditions (scripts, videos of performances, interviews, photographs) in the database eBOIARDO: https://edblogs.columbia.edu/ eboiardo/. All links are current as of 24 February 2018.
} 


\section{Sicilian puppet theater}

No art form has devoted as sustained and elaborate attention to the Orlando Innamorato and the Orlando Furioso as Sicilian puppet theater. ${ }^{2}$ Although today we are past the time when Orlando and his fellow knights relived their adventures a puntate every evening in teatrini across Sicily and beyond, we can still encounter puppeteers, especially in Palermo, Catania, and Siracusa, who regularly present episodes from the two poems. The plays may be adapted for audiences who are no longer familiar with the original stories, but the puppeteers themselves have an intimate knowledge of their sources and make meaningful choices as they adapt narratives for the stage. ${ }^{3}$

\section{Angelica}

The two most popular plays performed in Sicily today are the Innamorato's battle between Rinaldo and Orlando for Angelica and the Furioso's madness of Orlando. Since Angelica is central to both episodes, these plays offer ample material for a comparative examination of her character in contemporary Sicilian puppet theater.

Regarding Angelica's physical features, neither Boiardo nor Ariosto exoticize her beauty and a longstanding Italian and European artistic tradition has for the most part represented her with European features and dress. Most traditional Sicilian puppeteers have followed suit—with one difference. Although both Boiardo and Ariosto refer to Angelica as a blonde, matching Italian Renaissance standards for ideal beauty, most of the Angelicas I have encountered when attending puppet plays and visiting puppet museums in Sicily since 2000 have had dark brown hair, possibly reflecting the more Mediterranean colors of Sicilian women. ${ }^{4}$ When I asked members of the traditional public to

\footnotetext{
${ }^{2}$ For a comprehensive overview of Sicilian puppet theater, see the studies of Pasqualino, in particular L'opera dei pupi and Le vie del cavaliere dall'epica medievale alla cultura popolare.

${ }^{3}$ Most often their source is Lo Dico's La storia dei paladini di Francia, a 3000-page prose compilation first published 1858-1860 and still considered la bibbia dei pupari. Some intrepid puppeteers also go back to the original medieval and Renaissance sources while others are content adapting the scripts of their predecessors. My intention in this paper, in any case, is not to investigate which version of the story lies behind any particular play, but to give an idea of material based on the Innamorato and the Furioso available for classroom discussion. I therefore refer directly to Boiardo and Ariosto when examining the plays without considering Lo Dico's prose rendition.

${ }^{4}$ Students can compare Angelica puppets in versions of Orlando e Rinaldo per la bella Angelica by Enzo Mancuso's Compagnia Carlo Magno, Nino Cuticchio's Teatro Ippogrifo, and the Associazione Culturale Agramante di Vincenzo Argento e Figli, as well as in the puppet plays discussed below. See eBOIARDO, https://edblogs.columbia.edu/ eboiardo/sicilian-puppet-theater/puppet-plays/.
} 
describe Angelica, the reply was invariably that she was beautiful, tout court. Nor did her clothing set her apart as a foreigner. As the puppeteer Enzo Rossi explained, the traditional puppeteer's wife simply made sure that Angelica had the most elaborate and exquisite outfit. ${ }^{5}$

One can also find exceptions to the general Europeanization of Angelica. The puppeteer Enzo Mancuso (Associazione Carlo Magno, Palermo) remembers that his uncle constructed a brown-toned Angelica, remarking: "Questa è una Angelica che mio zio ha visto sempre così, ha visto sempre mulatta perché giustamente è indiana." ${ }^{6}$ The puppeteer Alfredo Mauceri (Compagnia dei Pupari Vaccaro-Mauceri, Siracusa) decided to render more visible Angelica's foreign status initially by constructing an Indian Angelica-complete with a bindi, nose earring, and henna tattoo-and subsequently by dressing her in Middle Eastern garb that, as the puppeteer himself explains, "non è certo un abito tipico del Catai, ma ciò consente di distinguerla dagli abiti europei indossati dalle altre dame."

In addition to giving Angelica a physical form, puppeteers also develop her character through action and dialogue. The question my students have found most compelling has been whether the plays pick up on and accentuate her more dangerous and seductive connotations or whether they instead bring her more in line with traditional precepts for female conduct. Most Sicilian puppet plays I've been able to film tend to temper her more compromising moments, perhaps to avoid any behavior that would be considered outside accepted norms. Regarding, for example, the staging of the Innamorato's opening scene in Charlemagne's court, the puppeteer Salvatore Oliveri (Compagnia Gaspare Canino di Salvatore Oliveri, Alcamo) depicts Angelica remaining silently at the side of her brother as he alone addresses Charlemagne and proposes a joust ("Angelica's entrance"). ${ }^{8}$ The fact that Argalia offers his sister's hand in marriage to the winner of the tournament also lessens the scandalous nature of Angelica's original proposal in which not only did she do all the talking while her brother stood by in silence, but she also invented a

\footnotetext{
${ }^{5}$ See eBOIARDO, https://edblogs.columbia.edu/eboiardo/interview-with-enzo-rossi/, "On the Angelica puppet."

${ }^{6}$ See eBOIARDO, https://edblogs.columbia.edu/eboiardo/sicilian-puppet-theater/ interviews/nino-and-enzo-mancuso/, "Enzo Mancuso shows his uncle's [Indian] Angelica puppet."

${ }^{7}$ His fuller comments can be found in Cavallo, "Encountering Saracens" 170-72.

${ }^{8}$ See eBOIARDO, https://edblogs.columbia.edu/eboiardo/sicilian-puppet-theater/ puppet-plays/storia-dei-paladini-oliveri/.
} 
false tale of woe to elicit pity and then openly offered her body ("la mia persona") without any reference to marriage (OI 1.1.28). When Oliveri subsequently gives voice to Angelica's thoughts via a soliloquy, the princess explains that she fell in love with Rinaldo at first sight (thus eliminating Boiardo's recourse to the fonte dell'amore) and plans to beg her father for his hand in marriage when he arrives in Cathay as a prisoner (Angelica's soliloquy). ${ }^{9}$

A particularly beautiful and stately Angelica can be found in the plays performed by Girolamo Cuticchio and his sons, Carmelo, Giacomo, and Franco (Teatroarte Cuticchio, Palermo). In a play entitled $L a$ morte di Truffaldino, Angelica can be seen falling in love with Rinaldo thanks to the fonte dell'amore ("Rinaldo e Angelica alle due fonti"), rescuing Rinaldo from the equivalent of the Rocca Crudele ("Angelica salva Rinaldo"), addressing her defenders at Albraca ("Angelica e Astolfo ad Albraca”), and rescuing Orlando from Dragontina's palace ("Angelica e Orlando al giardino di Dragantina"). ${ }^{10}$ While her agency is consistently foregrounded, the scenes depicting her penchant for Rinaldo also contain a touch of humor. No doubt some measure of the comical effect for contemporary audiences is due to the fact that Angelica speaks in the puppeteer's falsetto voice according to the tradition of Palermo, but the enamored princess's verbal exchanges with Rinaldo may also be designed to induce laughter, as when the no longer enamored knight responds to her: "Tu sei la mia desiderata Angelica? Il tuo sguardo mi sembra quello di una belva feroce!"11

In the Catanian tradition of the Marionettistica dei Fratelli Napoli, female roles are spoken by women, lending a softer touch to Angelica's character. In the scene from the Orlando Furioso in which Angelica and her beloved Medoro take leave of the shepherds who have sheltered them, the princess commands attention through her regal bearing and authority as Medoro stands silently by her side. Comic relief is provided instead by the banter of their rustic hosts ("Angelica and Medoro take leave of their shepherd hosts"). ${ }^{12}$

Angelica has also recently been used in puppet theater in less conventional ways. The Compagnia dei Pupari Vaccaro-Mauceri who, as mentioned above, has brought us an Indian and Middle Eastern

\footnotetext{
${ }^{9}$ Ibid.

${ }^{10}$ The four videos are available on eBOIARDO: https://edblogs.columbia.edu/ eboiardo/sicilian-puppet-theater/puppet-plays/morte-di-truffaldino/.

11"Rinaldo e Angelica alle due fonti," in particular 3:18-5:00.

${ }^{12}$ See eBOIARDO, https://edblogs.columbia.edu/eboiardo/sicilian-puppet-theater/ puppet-plays/amore-e-follia/.
} 
Angelica, has also added a soliloquy not to reveal the princess's own personal romantic desires (see Oliveri's Angelica above) but rather to expose the contradictions in the militancy of the Christian political establishment and even to question the existence of God. When early in the play, entitled Angelica, la fuga, the bishop Turpino censures Angelica in the presence of Charlemagne for having created discord among the Christian knights ("Dio vi ha castigato per il male che avete fatto"), she initially responds by placing responsibility upon her father and considering herself a victim of her beauty ("vittima della mia bellezza"). After she has escaped from Namo's tent in a subsequent scene, however, Angelica further reflects on Turpino's statement regarding God's punishment of her alleged misdeeds, reframing it to question its premises given the losses suffered by Christian troops at the hands of Agramante's army: "Ma che Dio è quel Dio che castiga i propri seguaci, che permette ad un uomo di uccidere un altro uomo senza muovere un solo dito? Dicono che esiste, ma io non lo vedo." ${ }^{13}$ The evil, in this case, is not an alluring damsel, but rather the unchecked tendency within mankind to aggress against others and wage war. ${ }^{14}$ Angelica can say this without contradiction in the context of the play because Galafrone's original plan to imprison all the knights who are enticed to fight in the Parisian joust is not disclosed.

The company's unorthodox presentation of Angelica continues when the maiden encounters Medoro, a darker-toned puppet with a white robe and turban..$^{15}$ The couple meets at night, near a well, with stars in the background. After Angelica has healed Medoro, the latter expresses the first stirrings of an emotion that will lead to their future union: "Sento qualcosa nascere dentro di me, non so se gratitudine o qualcosa di più grande; il tempo mi darà la risposta." They almost

\footnotetext{
${ }^{13}$ See eBOIARDO, "Angelica encounters the wounded footsoldier Medoro," in particular 00-1:46, https://edblogs.columbia.edu/eboiardo/sicilian-puppet-theater/ puppet-plays/angelica-la-fuga/.

${ }^{14} \mathrm{~A}$ questioning of the violence underpinning the epic genre (and of historical warfare, more generally) can be found in other contemporary plays. Giacomo Cuticchio's Il Viaggio di Astolfo sulla luna, for example, includes a reflection voiced by Astolfo from the vantage point of the moon that reminded one of my students of John Lennon's Imagine: "Se gli uomini comprendessero i mali che fanno sulla terra, si potrebbe vivere in pace, senza guerra, senza offendersi l'un con l'altro, senza esserci bisogno di lottare per aiutare i giusti e i deboli." See eBOIARDO. https://edblogs.columbia. edu/eboiardo/sicilian-puppet-theater/puppet-plays/viaggio-di-astolfo /, "Astolfo on the moon," 2:35-3:13.

${ }^{15}$ See eBOIARDO, "Angelica encounters the wounded footsoldier Medoro," in particular 1:46-5:26. https://edblogs.columbia.edu/eboiardo/sicilian-puppet-theater/ puppet-plays/angelica-la-fuga/.
} 
kiss before exiting arm in arm. The performance steers clear of the sexuality central to Ariosto's episode and places the emphasis instead on the value of individual sentiments in opposition to the earlier pronouncements of Church (represented by the Bishop Turpino) and State (represented by the Emperor Charlemagne) attacking Angelica's disruptive female beauty.

The most iconoclastic representation of Angelica, however, is that of Onofrio Sanicola, who portrays her as an overtly sexualized figure with partially exposed breasts. ${ }^{16}$ In the play La pazzia di Orlando, while Orlando sleeps in the foreground, Angelica has a sexual tryst with Medoro rendered through slow, stylized dance-like motions as romantic music and soft lights help to set the mood. ${ }^{17}$ And onstage sex between puppets is not the only surprise. Taking seriously Medoro's origin as a Moor and rank as foot soldier, Sanicola represents him through one of the small anonymous Saracen puppets generally brought on stage to die after a few sword strokes (these are commonly referred to as a suddateddu d'incolpo, or "little soldier who dies at the first hit") (Figure 1). Does the scene promote diversity through its biracial sex scene? Does it attempt to adhere more faithfully to the stated origin of Medoro as a Moor from Africa? Or does it mean to further justify Orlando's ensuing insanity in the context of the play just as Ariosto used Medoro's designation as an "african," a "vilissimo barbaro," and a "Saracino" (OF 42.38-40) to motivate Rinaldo's rage upon finding out the news of Angelica's sexual automony? My students have had various reactions. ${ }^{18}$

\section{Agramante's Biserta}

In an original play entitled L'Oro dei Napoli, staged by the Marionettistica dei Fratelli Napoli, family members from the only company of pupari remaining in Catania share and reenact their memories as they perform segments of puppet plays predominantly dealing with the final battle of three against three on the island of Lampedusa (referred to as Lipadusa in Ariosto's poem). In the process, King Agramante's attempt to prevent the destruction of his North African kingdom

\footnotetext{
${ }^{16}$ The fact of not being a "figlio d'arte," as Sanicola immigrated to Milan in his youth and acquired the theater of a retired puppeteer in the late 1980s, has perhaps spurred his willingness to defy puppet theater convention.

${ }^{17}$ See eBOIARDO, in particular 1:14-3:48, https://edblogs.columbia.edu/eboiardo/ sicilian-puppet-theater/puppet-plays/pazzia-di-orlando/.

${ }^{18}$ For some student's responses to this play, as well as to the Vaccaro-Mauceri play discussed above, see Cavallo, "Encountering Saracens."
} 


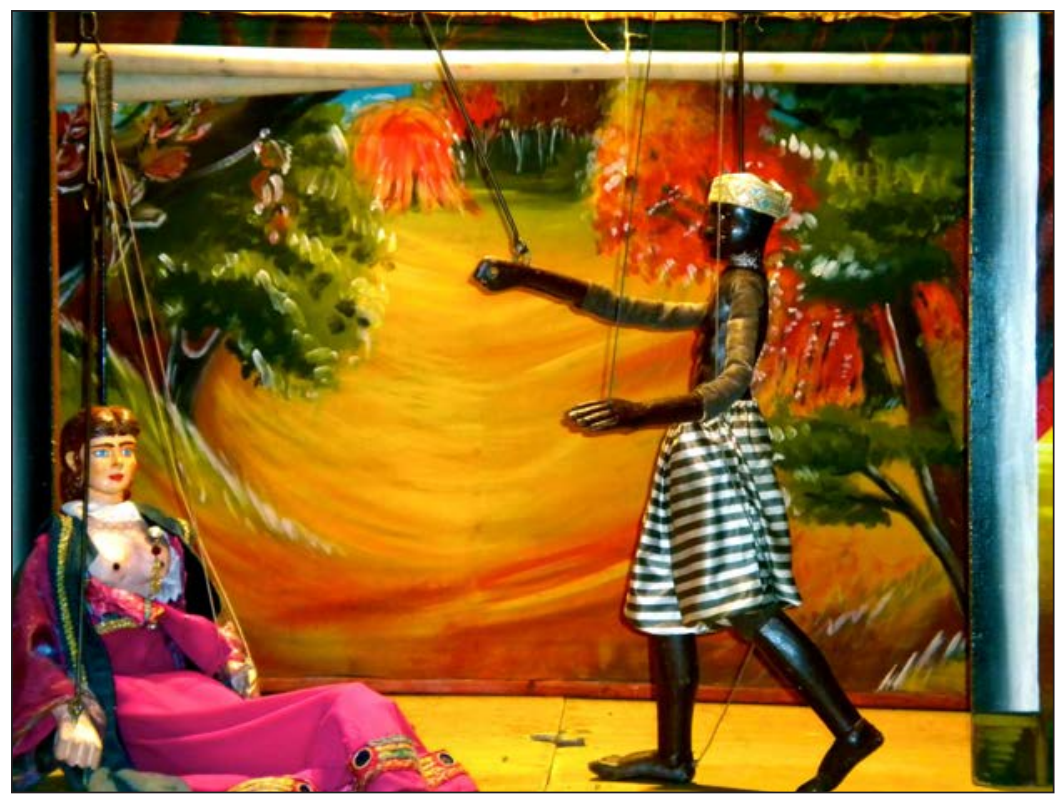

Figure 1. Angelica and Medoro in La pazzia di Orlando, by the Teatro drammatico dei pupi di Onofrio Sanicola, reproduced with the kind permission of Onofrio Sanicola.

parallels the efforts of the puppeteer Natale Napoli and his family to forestall the demise of traditional puppet theater in eastern Sicily. ${ }^{19}$

The play's opening puppet theater sequence moves from the sight of Biserta in flames to Agramante's grief and desperation as he observes the devastation of his capital city from nearby Lampedusa ("Battle of Lampedusa I")..$^{20}$ After Sobrino and Gradasso arrive in the nick of time to prevent his suicide and instill new hope, Agramante is persuaded to challenge Charlemagne to a decisive battle between each side's three greatest champions to determine the outcome of the war. The other puppet present in the scene is a common soldier who will be sent by Agramante to Biserta as a messenger.

Staging the sequence from Agramante's point of view, with added pathos elicited by his very position of standing by helplessly as his

\footnotetext{
${ }^{19}$ For a review of the overall play based on its 2002 debut, see Cavallo, "L'Oro dei Napoli."

${ }^{20}$ See eBOIARDO, https://edblogs.columbia.edu/eboiardo/sicilian-puppet-theater/ puppet-plays/oro-dei-napoli/.
} 
homeland goes up in flames, may already seem to go against the grain by granting center stage to the Saracen perspective. Yet an even more surprising move is in store for the public in the next scene when the puppet who had previously figured as Agramante's lowly messenger addresses the public directly in a soliloquy (he will be the only puppet accorded this privileged role in the course of the play) ("L'Oro dei Napoli, Messenger's Soliloquy I"). ${ }^{21}$ The soldier, like Sanicola's Medoro puppet, is a small-framed Moorish suddateddu d'incolpo, suggesting his low social status. This contrasts with the elevated role afforded him in the production in which he returns periodically as the spokesperson for, variously, a downtrodden Catanian society, a destroyed puppet theater tradition, and a disenfranchised global population. In his first speech, the common soldier acts as a witness not only to the annihilation of Agramante's Biserta, but also to the cessation of Sicilian puppet theater in 1950s Catania. In this, his function is parallel to that of the Napoli family members who also bear witness to the same history.

By the end of the play it becomes clear that the family's identification with the Saracens is not tied to any particular cultural or religious preference, but to their position as defeated and powerless underdogs in the final cantos of Ariosto's poem. The play creates connections to Christian characters in their suffering as well. In another segment, for instance, after Alessandro Napoli notes that the traditional workingclass public identified with Rinaldo as a fellow victim of injustice, the family performs the heartbreaking farewell between Rinaldo and his wife Clarice after Charlemagne has unjustly condemned him to exile upon the treacherous instigation of Gano ("Rinaldo exiled, from 'L'Oro dei Napoli'").$^{22}$ In addition, in the play's climactic scene, the tragic death of Brandimarte during the battle leads to a symbolic merging of the fallen warrior with Natale Napoli who, as his widow explains, suffered a heart attack while performing the episode precisely on the island of Lampedusa in 1978 ("Battle of Lampedusa II"). ${ }^{23}$ The play concludes organically merging puppeteers and puppets as both take part in Brandimarte's funeral procession ("Battle of Lampedusa III"). ${ }^{24}$ After the family's exit, the only figure still onstage is their erstwhile spokesperson, the lowly Saracen soldier, now seated in the chair that various family members had used during the performance, ominously silent with no one left to give him voice and gestures.

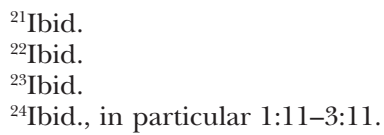




\section{The Tuscan-Emilian epic maggio}

The maggio epico, also called maggio drammatico to distinguish it from maggi lirici (springtime festival songs), has recently been shown to have antecedents dating back to the Renaissance, but in its current form is documented in the Tuscan-Emilian Apennines from the late $1700 \mathrm{~s} .{ }^{25}$ The plays, generally performed in a natural outdoor setting on a summer Sunday afternoon, consist of singers dramatizing stories with choreographed battles using swords and shields in a symbolic contest between good and evil. Unlike opera lirica with its sophisticated and virtually unlimited variety of melodies, this popular form of opera depends almost exclusively on the same melody which is used throughout for singing quatrains, occasionally interspersed with two additional melodies for the five-verse sonetto or arietta, in dramatic or joyous moments, and for the ottava rima, generally reserved for the most emotionally-charged or tragic scenes.

The Reggio Emilia Apennines in particular feature adaptations of medieval and Renaissance chivalric epics pitting Christian paladins against Saracen foes. ${ }^{26}$ The distinguishing characteristics between the Saracen and Christian knights are simple variations in the maggerino's costume and shield design, while the female damsels don Renaissancestyle gowns regardless of origin or creed. The Saracens, like their Christian counterparts, are portrayed by maggerini who remain recognizable as members of the community, without make-up or masks. The company best known for its epic productions, the Compagnia Maggistica Monte Cusna di Asta (from the outskirts of Villa Minozzo [RE]), regularly performs maggi based on Boiardo and Ariosto: Luca Sillari's Orlando Innamorato and the anonymous Rodomonte, respectively. Both maggi feature female Saracen characters, Angelica in the first and Doralice in the second, who take on a role that goes beyond-or even against-their depiction in the original poems.

\section{Angelica in the maggio Orlando Innamorato}

Luca Sillari's maggio Orlando Innamorato gives ample space to five female characters, Bradamante and Fiordelisa on the Christian side, and Angelica, Marfisa, and Dragontina among the non-Christians.

\footnotetext{
${ }^{25}$ For the epic maggio's forerunners in sixteenth-century Tuscany, see Feo. For the tradition as it developed over the last two centuries, see in particular Fioroni and Vezzani; Giusti; Magrini; and Vezzani.

${ }^{26}$ As Fontana remarks: "Sono queste le terre dove ancora risuona la tromba epica del Boiardo e dell'Ariosto, i due più grandi poeti reggiani di tutti i tempi” (14).
} 
Angelica sets off the action in the maggio, as she does in Boiardo's poem, by proposing a joust, but from the start Sillari portrays a humanized and more openly sympathetic character by eliminating both the false story of Angelica's expulsion from her realm and Galafrone's duplicitous plan to use his daughter to capture and imprison the jousting knights ("Arrival of Angelica"). ${ }^{27}$ When Ferraguto declares his infatuation, Angelica reflects upon the deceptive nature of love itself: "spesso il cuor segue un miraggio / certo sei di ciò che vuole?" (19). Whereas in the poem Angelica simply flees the violent combat between Ferraguto and her brother, in the maggio she shows greater concern for her sibling. Seeing that Argalia cannot prevail against the fierce Ferraguto with his enchanted armor, Angelica magically places the Spanish knight in a dreamlike state and commands the wind to transport him to the Arden Wood. Although, as in the poem, her magic is powerless to release her from loving Rinaldo, she later uses it to the advantage of all those entrapped in Dragontina's garden in a way that develops the Boiardan episode in a new direction.

Dragontina's garden is one of the pivotal sites of Boiardo's poem, involving various characters who arrive at different moments. The site is not only likewise central to Sillari's maggio, dominating the action in five scenes between stanza 56 and stanza 192 in a 250-stanza work, but it is further elaborated through additional features with markedly symbolic meanings. First of all, the episode is distanced from any connection to the conflict between Christian Europe and the Saracen world beyond its borders. This move away from inter-religious hostility was already present at various moments in Boiardo's original, from the imprisoned knights who didn't remember whether they were "saracino, o cristiano" (OI 1.9.73), to a chivalrous Ranaldo's plea for Fiordelisa to tell him what distressed her "per lo Iddio del celo, e per Macone" (OI 1.11.47), to the liberated knights' willingness to help Angelica in a defensive war in Albraca that cut across religious lines (OI 1.14.49). In Sillari's rendition, the rejection of collective identities is even more explicitly stated in an ottava rima exchange between Brandimarte and Fiordelisa prior to approaching Dragontina's garden. When the knight tells his beloved that he must go fight against a threat from the East-"Di andare in guerra io non son contento / Da Oriente viene una minaccia ardita" (76) — the wise maiden immediately rejects distinctions based on geographical origins in recognition of the com-

\footnotetext{
${ }^{27}$ See eBOIARDO, https://edblogs.columbia.edu/eboiardo/epic-maggio/performances/maggio-orlando-innamorato/.
} 
mon humanity of all: "Oriente ed Occidente pari sono / Se al centro della vita poni l'uomo" ("Dragontina's Palace III"). ${ }^{28}$ Second, Sillari adds a scene not present in the poem in which the Christian Bradamante and the Saracen Marfisa initially meet and engage in combat to test their valor in quintessential Arthurian fashion, after which, at Fiordelisa's urging, they agree to join forces against Dragontina in order to help those in need (117-126; "Dragontina's Palace IV"). ${ }^{29}$ The fact that the two donne guerriere are of different faiths is of no apparent consequence. Finally, the Cathayan princess herself, through her enhanced role in the episode, substitutes distinctions based on religion or geography with the division between good and evil actions on the part of individuals.

In Boiardo's poem, Angelica heads to Dragontina's garden out of self-interest when she decides to enlist Orlando in her defense at Albraca. She learns of Fiordelisa's predicament in a Circassian tower in which they are both captured (OI 1.14.34-37), but then escapes alone thanks to the magic ring that renders her invisible and eventually destroys Dragontina's garden. Fiordelisa, who had been heading to the garden with Ranaldo before she was kidnapped and imprisoned in the tower, is rescued by the paladin outside Falerina's garden in Orgagna, and she eventually leads him to the location of Dragontina's garden, only to find that it has vanished. In Sillari's maggio, Fiordelisa, Rinaldo, and Angelica are all involved in the episode, albeit in different ways. Fiordelisa twice asks Rinaldo to liberate Dragontina's prisoners, but both times he refuses, citing more urgent missions. In response to Fiordelisa's initial plea for help ("Dragontina's Palace V"), ${ }^{30}$ he recalls his previous vow to challenge the treacherous Truffaldino for the murder of Albarosa (142) ("Dragontina's Palace III"). ${ }^{31}$ Fiordelisa accordingly leads him to Truffaldino, who in the meantime has taken Angelica captive via trickery ("Truffaldino I")..$^{32}$ After Rinaldo kills the traitor and frees Angelica, Fiordelisa renews her request for his assistance, informing him that Orlando is among Dragontina's imprisoned knights ("Truffaldino II"). ${ }^{33}$ When Angelica proposes a joint rescue

\footnotetext{
${ }^{28} \mathrm{Ibid}$., in particular 00:36-2:40. Fiordelisa is the poem's foremost figure of knowledge (Cavallo, The World Beyond Europe 218). Sillari imagines that she and Brandimarte are already Christian in order to avoid any incongruency with their status in the Rodomonte (according to author's personal communication).

${ }^{29}$ See eBOIARDO, in particular 0:00-00:59, https://edblogs.columbia.edu/eboiardo/ epic-maggio/performances/maggio-orlando-innamorato/.

${ }^{30}$ Ibid.

${ }^{31}$ Ibid.

${ }^{32}$ Ibid.

${ }^{33}$ Ibid.
} 
effort ("liberiamo i paladini"), Rinaldo replies that his more pressing duty is to return to France to save Charlemagne from Gradasso and he advises Angelica to forget him ("risana ogni ferita / Scordandoti di me" [168]). Placing the chivalric code before her personal emotions, Angelica sets off for Dragontina's garden, effectively taking on the role of Fiordelisa's champion that Ranaldo had filled in the Innamorato episode.

The ensuing confrontation between Angelica and Dragontina is undoubtedly the most memorable moment of the episode, and perhaps of the entire maggio. In the poem, Angelica furtively enters the garden and uses her magic ring to mentally liberate Orlando, who then releases the other enchanted knights. As a result of the ring's spellbreaking properties, Dragontina and her garden suddenly disappear (OI 1.14.47). In the maggio, however, Dragontina is a more maleficent opponent who is also harder to defeat. Indeed, she imprisons not only Orlando ("Dragontina's Palace I") and Brandimarte ("Dragontina's Palace II"), but subsequently also Marfisa and Bradamante by using the two enamored knights as her champions against the newcomers ("Dragontina's Palace IV"). ${ }^{34}$ Thus when Angelica is led by Fiordelisa to the site, she will need to save not only Orlando and Brandimarte, but the poem's two formidable donne guerriere as well. Although Rinaldo had earlier stated that only Angelica's magic could prevail against Dragontina's wiles (140), the spell-breaking ring is not sufficient to destroy the garden. After Angelica and Fiordelisa set Marfisa and Bradamante free ("Dragontina's Palace VI"), ${ }^{35}$ and Angelica uses her ring to bring the enamored knights to their senses, Dragontina conjures up a tempest that reduces the knights to "inermi bambinelli" writhing on the ground in pain (174-175). With the knights' valor thus undermined, Angelica must come up with a way to save them using weapons in her own arsenal. She thus challenges Dragontina to a duel of magic which begins when the fairy calls upon a fire-breathing dragon from the inferno and orders it to direct its rage against the maiden (177-178) ("Dragontina's Palace VII"). ${ }^{36}$ Angelica, in turn, brings forth a lion from the Black Mountains. While Dragontina's "rettile fatato" is the essence of evil ("d'ogni male ha in se l'essenza"), Angelica's lion is armed with an instinct for survival (180-181) and carries positive symbolic connotations (one may think of C.S. Lewis's

\footnotetext{
${ }^{34}$ Ibid.

${ }^{35}$ Ibid.

${ }^{36}$ Ibid.
} 
choice of a lion as the savior figure in The Chronicles of Narnia). In this way, what was originally an episode in which Angelica turned a situation to her advantage thanks to her magic ring, here becomes a fierce conflict between two creatures symbolizing moral opposites. Through her victory, the Saracen Angelica not only liberates all the knights, but also represents the triumph of good over evil.

Dragontina dies filled with ire and cursing those present in a final ottava rima imprecation that concludes with the hope of seeing them all in hell by winter (183). Angelica, on the other hand, shows no rancor toward her defeated opponent and focuses instead on the knights' newfound freedom: "morta è ormai la poverina / Cavalier liberi siete" (184). In the poem, after Angelica frees Orlando she immediately enlists him to help defend her against Agricane at Albraca. In the maggio, however, she responds to Orlando's declaration of love ("da una donna fui salvato / Da colei che il cuor mio brama") with a confession of her past deceit and an admonition to forget her: "Non guardar più quella dama / Che colei ti ha un dì ingannato" (187). Not only does Angelica come clean with Orlando and refuse to capitalize on the situation, but she goes on to sing an ottava rima (her final verses in the maggio) in which she considers herself "prigioniera di una triste sorte" and takes leave of everyone to go "per il mondo [ . . . ] errando" (188). Her words are enough to cure the knight of his lovesickness, and he is apparently thereby also spared the trouble of going insane from jealousy in the future. As he confides to Brandimarte: "Più non ci sarà fanciulla / Che potrà rubarmi il cuore / Penso a Carlo imperatore" (190).

\section{Doralice in the maggio Rodomonte}

Angelica is physically absent from the Ariostan text regularly performed by the same company of maggerini in Asta, entitled Rodomonte. This is not for lack of space, since the anonymous maggio, consisting of 554 stanzas in its unabridged form, devotes substantial attention to the vicissitudes of other Saracen characters who are developed, moreover, in their own right and not treated simply as enemies of the Christian heroes. ${ }^{37}$ The prominence of the Saracens is suggested by the maggio's

\footnotetext{
${ }^{37}$ The maggio was first transcribed by the company's capomaggio (director) Giordano Zambonini in 1975. The unabridged version, which takes around five hours to complete, was last performed in 2000 , but was not videotaped. The version available on eBOIARDO is an abridged version from 2005. For a comparison of the Rodomonte with a more conservative maggio, Romolo Fioroni's Roncisvalle, regularly performed by a neighboring maggio company, see Cavallo, "National Political Ideologies."
} 
very title, which replaces Orlando's name with that of the fierce Algerian warrior king. The maggio goes on to feature episodes that place Christians and Saracens in analogous situations. For example, after Orlando arrives at the tree inscribed with the names of his beloved Angelica and her lover Medoro and thereby loses his sanity (23-34), Rodomonte learns that his betrothed Doralice prefers another and thus perhaps even more visibly than in the original poem parallels Orlando in his madness (119-124, 128-129). The Rodomonte's most novel treatment of a Saracen character, however, is that of the Spanish princess herself, whose rapport with Mandricardo comprises one of the most developed episodes in the maggio.

The action begins with Charlemagne's announcement that King Agramante has invaded his territory motivated by a desire for revenge, leaving out the question of their different religious creeds ("Carlomagno on Agramante's attack"). ${ }^{38}$ We then move directly to the Saracen side: surrounded by the Christian army, Agramante sends a messenger to look for military support ("Agramante sends messenger for reinforcements"), ${ }^{39}$ while Doralice warns her new beau Mandricardo that her old flame Rodomonte is drawing near ("Doralice warns Mandricardo of Rodomonte's approach"). ${ }^{40}$ As in the poem, the two knights engage in battle until Agramante's messenger arrives and Doralice beseeches them to stop fighting and lend a hand to the Saracen cause ("Rodomonte fights Mandricardo") ${ }^{41}$ Having omitted the episode of Mandricardo's ruthless abduction of Doralice in the original poem, however, the maggio sets out right from this initial scene to underscore the tender affection between the two lovers and to document in particular the maiden's concern for her knight's well-being.

In the ensuing episode at Agramante's camp in which Doralice is compelled to choose between the two rivals, the maggio continues to treat her bond with Mandricardo as more than sexual ("Doralice chooses Mandricardo over Rodomonte").$^{42}$ Whereas Ariosto remarks that the Tartar lord's confidence in being chosen was due to the fact that "più fiate e più di piatto / con lei fu mentre il sol stava sotterra" (OF 27.106.6-7), the maggio's Doralice explains instead to Mandricardo that her choice was the will of their God: "Fu del ciel l'alto decreto / fu voler del nostro Dio" (125). Their sanctioned union is marked by

\footnotetext{
${ }^{38}$ See eBOIARDO. https://edblogs.columbia.edu/eboiardo/rodomonte/.

${ }^{39}$ Ibid.

${ }^{40}$ Ibid.

${ }^{41}$ Ibid.

${ }^{42}$ Ibid.
} 
the singing of two ariette, the verse form that is used sparingly in the maggio tradition to underscore either dramatic or joyous moments:

Doralice

Unico mio tesoro amato e dolce bene da mille e più catene i nostri cuor legò i nostri cuor legò. (126)

Mandricardo In te confido ormai
tutti gli affetti miei
la sposa mia tu sei
la pace del mio cuor
la pace del mio cuor. (127)

The maggio departs most substantially from Ariosto's treatment of Doralice as superficial and sensuous in the subsequent episode of Mandricardo's death ("Ruggiero fights Mandricardo")..$^{43}$ In the original poem, after Ruggiero delivers a fatal blow to his Tartar opponent, Doralice's tears mean nothing since, the narrator suggests in an aside, she might already be enlisting Ruggiero to satisfy her sexual needs if it weren't so unseemly: "Proveder le convien d'un che gagliardo / sia notte e dí ne' suoi bisogni” (OF 30.73.3-4). The maggio, by contrast, transforms Ariosto's fickle Doralice into a model of devotion and supplies the heartfelt lament missing from the poem that culminates in another pair of ariette, this time in tragic tones:

Doralice

$$
\begin{aligned}
& \text { Ah! qual barbara sorte } \\
& \text { il ciel mi ha destinato } \\
& \text { veder lo sposo amato } \\
& \text { che giace estinto al suol } \\
& \text { che giace estinto al suol. } \\
& \text { Ah! caro amato bene } \\
& \text { mai più ti vedrò io } \\
& \text { oh! Caro sposo mio } \\
& \text { voglio morir con te } \\
& \text { voglio morir con te (167-168) }
\end{aligned}
$$

Doralice's final words in the maggio, in response to Marsilio's plea that she resign herself to the will of the gods, is her declaration that "Il dolor mi stringe al cuore / e rapisce i sensi miei" (169). Whereas Ariosto's narrator surmised that Doralice's sentiments went no further 
than her physical pleasure, in the maggio, on the contrary, the pain of grief takes over her entire being. Doralice's sincere love for Mandricardo not only lends greater humanity to both Saracen characters throughout the extended sequence, but at its tragic conclusion elicits complicity and compassion, rather than a distainful chuckle, on the part of the spectator.

In conclusion, the continued adaptation of Boiardo's Orlando Innamorato and Ariosto's Orlando Furioso in popular performance traditions half a millennium after their original appearance is a testament to both the lasting appeal of these poems and the perennial issues they evoke. Although folk traditions have often been considered a conservative form of cultural expression in that they purportedly aim to convey values passed down from previous generations, even a brief look at contemporary puppet plays and epic maggi shows that the representation of the traditional Saracen enemy-and of the world beyond Christian Europe in general-is anything but a uniform or static re-enactment. While both traditions inherited a backdrop presupposing conflict between Christians and Saracens, we can find performances (especially, but not only, recent ones) that actively question confrontations based on ethnicity or religion, challenge conventional societal attitudes, seek to promote understanding across borders, and encourage our compassion for those who suffer regardless of their origin. In this way, puppeteers and maggerini voice their views on pressing issues of our time-something that for me makes them especially viable for classroom discussions of the Italian Renaissance romance epic. 